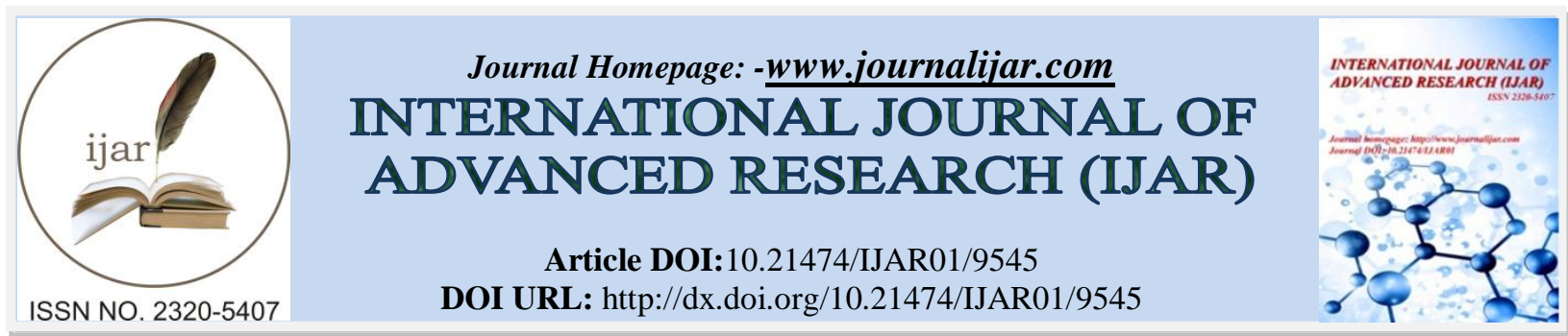

RESEARCH ARTICLE

\title{
BACTERIAL CONTAMINATION OF SOME VEGETABLES SOLD IN MAJOR MARKETS IN ADO- EKITI, NIGERIA.
}

\section{Oluwapelumi Bernard Oluboyo ${ }^{1}$, Oluwabunmi G. Olojede ${ }^{1}$, Funmilayo Janet Akinseye ${ }^{1}$, Yomi Richard} Akele $^{1}$, Adeola Olanrewaju Oluboyo ${ }^{1}$ And Funmilayo A. Adewumi ${ }^{2}$.

1. Department of Medical Laboratory Science, College of Medicine and Health Sciences, Afe Babalola University, Ado-Ekiti, Nigeria.

2. Department of Medical Microbiology and Parasitology, College of Medicine, Ekiti State University, Ado-Ekiti, Ekiti State, Nigeria.

\section{Manuscript Info}

\section{Manuscript History}

Received: 08 June 2019

Final Accepted: 10 July 2019

Published: August 2019

Key words:-

Bacteria, vegetables, contamination, markets, susceptibility.

\section{Abstract}

Consumption of vegetables contaminated with pathogens is a common source of infections. This study investigated bacterial contamination of vegetables sold in major markets in Ado-Ekiti, Nigeria. Sixty samples comprising of 20 samples each of Brassica oleracea, Cochorus olitorius, and Amaranthus hybridus were examined. Bacteriological procedures were followed in the isolation and identification of bacteria from culture media. Antimicrobial susceptibility of the isolates was done using the disk diffusion method. Sixty six bacteria were isolated from 60 vegetable samples. Of these isolates, Salmonella spp recorded 43.3\%, followed by Citrobacter freundii $18.3 \%$, Klebsiella spp $15.0 \%$, Enterobacter spp $11.7 \%$, Proteus spp and Alcaligenes spp 5.0\% each, Escherichia coli and Providencia spp 3.3\% each and Vibrio spp 1.7\%. The prevalence of the isolates on 20 samples of Brassica oleracea decreased in the order of Salmonella species $55.0 \%$, Citrobacter species $20.0 \%$, Alkaligenes species $10 \%$, Pseudomonas aeruginosa, Enterococcus species, Escherichia coli, Proteus mirabilis and Providentia species 5\% each. The most frequent bacteria isolated on 20 samples of Cochorus olitorius was Salmonella species $50.0 \%$, followed by Citrobacter species $15.0 \%$. Vibro species and Alkaligenes species recorded $5.0 \%$ each. Enterobacter species recorded the highest frequency $30.0 \%$ on the 20 samples of Amaranthus hybridus, followed by Salmonella species and Klebsiella species $25.0 \%$ each, Citrobacter species 20.0\%, Pseudomonas aeruginosa and Escherichia coli $5.0 \%$ each. All isolates were sensitive to ofloxacin and ciprofloxacin but resistant to augmentin, ampicillin and cefuroxime. It is essential to control the sources of vegetable contamination to minimize risk of infections especially in vegetables consumed raw. 


\section{Introduction:-}

Vegetables are leafy outgrowth or plant parts used as food (Yusuf et al., 2004). They contain carbohydrates, proteins, vitamins, minerals as well as trace elements (Farooq et al., 2008; Gharavi et al., 2002 and Itanna, 2002) necessary for nourishment and protection of the body. Vegetables are grown throughout the year relying on rain water in raining season and use of irrigation during dry season. Vegetable consumption has been associated with the decline of hazards of specific diseases (Hung et al., 2004). However, they are often contaminated with enteric microorganisms the incidence of which reflects the sanitary quality of the processing steps of food production as well as the microbial flora of the raw product at the time of processing (Ngugen et al., 1994). Vegetable pollution in agricultural land has been regarded as the major source of infections in humans.

Pre-harvest activities such as cultivation, manuring and irrigation; and post-harvest handling of vegetables such as storage, transportation, food processing for consumption render the produce to microbial contaminations (Erkan and Vural, 2008). As an end result, use of waste water polluted with human and animal feces to wash vegetables or irrigate vegetable garden without proper disinfection has been considered responsible for high rates of vegetable contamination (Erkan and Vural, 2008). Pathogens on the soil may contaminate crops directly when torrential rainfall causes splashes of soil on the leaves of vegetables (Heaton et al., 2008).

Organic fertilizers enrich the soil and cause luxuriant growth of vegetables. However, sewage sludge, animal manures and slurries, and abattoir wastes use to fertilize farmland equally contaminate land with pathogens directly (Natvig et al., 2002; Avery et al., 2005). These processes eventually lead to pathogen entering into the food chain (Machado et al., 2006).

Food-poisoning outbreaks have been traced to the consumption of contaminated vegetables due to unhygienic handling of the farm produce (Brackett et al., 1999). Infections from vegetables are almost inevitable when such produce are eating raw without further processing (Brandl et al., 2006).

Salmonella is among the most important foodborne pathogens all over the world contaminating fresh vegetables. Salmonellosis can cause gastroenteritis, bacteremia, typhoid fever and focal infections (Darwin and Miller, 1999). In Nigeria, morbidity associated with illness due to Salmonella is on the increase and has resulted to death in some cases (Adabara et al., 2012; Ibekwe et al., 2008). The prevalence of typhoid fever was found to be relatively high (42\%) in Ado-Ekiti (Oluyege et al., 2015).

Prevalence of enteric fever and bacteria enteritis has continued to increase rapidly in Ekiti State (Ajibade, 2012; David et al., 2015). The carriage rate of the Salmonella typhi among undergraduate students of Ekiti State University, Ado-Ekiti was 33.86\% (David et al., 2015; Ajibade, 2012). The researchers reported clinical evidences of high rate of Salmonella infection among the undergraduate students $(58.90 \%)$. This study evaluated bacterial contamination of Brassica oleracea (Cabbage), Amaranthus hybridus (African spinach/green) and Cochorus olitorius (Jute leaves) commonly consumed in Ekiti State.

In Nigeria, Brassica oleracea is called "Efo Oyinbo" or "Eso Kabeeji" in Yoruba, "Kabeji" in Igbo and Hausa. Amaranthus hybridus is called "Efo-tete" in Yoruba, "Inine" in Igbo and "Allayahu" in Hausa. Cochorus olitorius (Jute leaves/saluyot leaves and Jews mallow) is called "Ewedu" in Yoruba, "Kerenkere" in Igbo and "Ayoyo" in Hausa.

\section{Materials and methods:- \\ Study area}

Ado Ekiti is a city in the Southwestern part of Nigeria. It is the State Capital and Headquarters of Ekiti State. AdoEkiti is located between latitude $7^{\circ} 34^{\prime}$ and $7^{\circ} 44^{\prime}$ north of the equator and longitude $5^{\circ} 11^{\prime}$ and $5^{\circ} 18^{\prime}$ east of the Greenwich Meridian on total land area of $36.7 \mathrm{Km}^{2}$ (Olusegun, 2013). Its population is 424,340 (WPR, 2018).

\section{Sample size}

A total of Sixty (60) vegetable samples were used in the study. This comprised of ten (10) collections of each of the three vegetables in each of the two selected markets. The vegetables under study were: Brassica oleracea (Cabbage), Amaranthus hybridus (African spinach) and Cochorus olitorius (Jute leaf) identified at the Science Department of Afe Babalola University, Ado-Ekiti. The markets visited were "Oja Oba" market and "Bisi" market. 


\section{Sample collection}

Jute leafs were collected at 8.45 a.m., African spinach were collected at 9.22 a.m. while Cabbage were collected at 10.00 a.m. Each of the samples was collected into a sterile polythene bag and transported immediately to the laboratory for analysis.

\section{Sample processing}

Each sample was swab with a sterile swab sticks and inoculated aseptically into nutrient broth and incubated for 24 hours at $37^{\circ} \mathrm{C}$. Another swab collection was used to inoculate selenite $\mathrm{F}$ broth and incubated for 48 hours at $37^{\circ} \mathrm{C}$. After 24 hours, the inoculated nutrient broths were subcultured on MacConkey agar while inoculated Selenite F broths were subcultured on deoxycholate agar (DCA). The plates were incubated at $37^{\circ} \mathrm{C}$ for 24 hours (Cheesebrough, 2006). All isolates were characterized using standard microbiology and biochemical tests as described by Barrow and Feltam (2004); Garrity et al (2005) and Cheesebrough (2006).

\section{Antimicrobial assay}

Antibiotics sensitivity test was done using the disk diffusion method (Cheesbrough, 2006). Overnight broth cultures of isolates were adjusted to match that of 0.5 McFarland standards by diluting with distilled water or incubating further. Sterile swab stick was used to spread the inoculums evenly on Muller Hinton agar. Antibiotic disc (Rapid laboratories) of gentamicin, ampicillin, augmentin/clavulante, ofloxacin, ceftaxidime, cefuroxime, and ciprofloxacin were placed aseptically on the agar and incubated for 24 hours at $37^{\circ} \mathrm{C}$ (Cheesbrough, 2006). Zone of inhibition was measured in duplicates and sensitivity was determined by comparing the mean inhibition diameter with that of standard antibiotics sensitivity table (Clinical and Laboratory Standards Institute (CLSI), 2003).

\section{Statistical analysis}

Data generated in this study were subjected to standard statistical test using statistical package for social science (SPSS) version 20. The frequencies of bacteria were recorded in percentages, mean, and standard deviations.

\section{Results:-}

A total of 66 different organisms were isolated from the 60 vegetables (Table 1). Of the 60 vegetables examined, the most common bacteria isolated was Salmonella species 26 (43.3\%), followed by Citrobacter species 11(18.3\%), Klebsiella species 9 (15.0\%), Enterobacter species 7 (11.7\%), Alkaligenes species and Proteus species 3 (5.0\%) each, Pseudomonas aeruginosa and Escherichia coli recorded 2 (3.3\%) each. The least frequent bacterium was Vibro species $1(1.7 \%)$.

Eight (8) different bacteria were identified on Cabbage and on African spinach and 4 bacteria on Jute leaves. The frequencies of the bacteria isolates on 20 samples of Cabbage decreased in the order of Salmonella species 11 (55.0\%), Citrobacter species 4 (20.0\%), Alkaligenes species 2 (10\%), Pseudomonas aeruginosa, Enterococcus species, Escherichia coli, Proteus mirabilis and Providentia species 1 (5\%) each. Enterobacter species recorded the highest frequency $6(30.0 \%)$ on the 20 samples of African spinach, followed by Salmonella species and Klebsiella species 5 (25.0\%) each, Citrobacter species 4 (20.0\%), Pseudomonas aeruginosa and Escherichia coli 1 (5.0\%) each. Isolates recovered on 20 samples of Jute leaves decreased in order Salmonella species 10 (50.0\%), by Citrobacter species 3 (15.0\%) and Vibro species and Alkaligenes species $1(5.0 \%)$ each.

Of the 60 vegetables examined, Salmonella typhimurium recorded the highest frequency 20 (33.3\%), occurring virtually in all the vegetables (Table 2). Salmonella typhi and Salmonella paratyphi A each recorded prevalence of 1(1.7\%) while other Salmonella recorded 4 (6.7\%).

Out of the 20 samples of cabbage, 11 Salmonella species were isolated (Table 2) with Salmonella typhimurium recording a prevalence of $9(45.0 \%)$ while other salmonella recorded 2(10\%). Five (5) Salmonella species were isolated from the 20 samples of African spinach (Table 2). Salmonella typhimurium recorded the highest frequency of $3(15.0 \%)$ while S. paratyphi A and other salmonella recorded $1(5.0 \%)$ each. Of the 20 samples of Jute leaf, $S$. typhimurium had the highest frequency of $8(40.0 \%)$, Salmonella typhi recorded frequency of $1(5 \%)$ while $1(5.0 \%)$ was recorded against other salmonella.

Enterobacter species recorded sensitivity to gentamicin, ofloxacin, and ciprofloxacin and resistance to ampicillin, augmentin/clavulanate, ceftaxidime and cefuroxime (Table 3). Citrobacter species recorded sensitivity to only ofloxacin and ceftaxidime. Providentia species equally recorded sensitivity to ofloxacin, ceftaxidime and 
ciprofloxacin. Klebsiella species and Pseudomonas aeruginosa were sensitive to only ofloxacin and ciprofloxacin. Escherichia coli recorded sensitivity against gentamicin, ofloxacin, ceftaxidime and ciprofloxacin (Table 3).

Vibrio species recorded sensitivity against gentamicin, ofloxacin, ceftaxidime and ciprofloxacin (Table 4). Proteus species, Alkaligenes species and other salmonellae recorded gross resistance against the tested antibiotics; showing sensitivity against only ofloxacin and ciprofloxacin (Table 4). While Salmonella typhimurium recorded sensitivity to only ciprofloxacin, Salmonella typhi and Salmonella paratyphi A recorded sensitivity to ofloxacin, ceftaxidime and ciprofloxacin and resistance to all other tested antibiotics.

Table 1:-The frequency of various organisms isolated from the vegetables.

\begin{tabular}{|l|l|l|l|l|}
\hline Organisms & \multicolumn{2}{|c|}{ Vegetables } & Total (\%) \\
\hline & Cabbage (\%) & $\begin{array}{l}\text { Jute leaf }(\%) \\
\mathrm{n}=20\end{array}$ & $\begin{array}{l}\text { African spinach (\%) } \\
\mathrm{n}=20\end{array}$ & $\mathrm{n}=60$ \\
\hline Salmonella spp & $11(55.0)$ & $10(50.0)$ & $5(25.0)$ & $26(43.3)$ \\
\hline Citrobacter freundii & $4(20.0)$ & $3(15.0)$ & $4(20.0)$ & $11(18.3)$ \\
\hline $\begin{array}{l}\text { Pseudomonas } \\
\text { aeruginosa }\end{array}$ & $1(5.0)$ & $0(0.0)$ & $1(5.0)$ & $2(3.3)$ \\
\hline Klebsiella spp & $4(20.0)$ & $0(0.0)$ & $5(25.0)$ & $9(15.0)$ \\
\hline Vibrio spp & $0(0.0)$ & $1(5.0)$ & $0(0.0)$ & $1(1.7)$ \\
\hline Enterobacter spp & $1(5.0)$ & $0(0.0)$ & $6(30.0)$ & $7(11.7)$ \\
\hline Alcaligenes species & $2(10.0)$ & $1(5.0)$ & $0(0.0)$ & $3(5.0)$ \\
\hline Escherichia coli & $1(5.0)$ & $0(0.0)$ & $1(5.0)$ & $2(3.3)$ \\
\hline Proteus spp & $1(5.0)$ & $0(0.0)$ & $2(10.0)$ & $3(5.0)$ \\
\hline Providencia spp & $1(5.0)$ & $0(0.0)$ & $1(5.0)$ & $2(3.3)$ \\
\hline TOTAL & $26(130.0)$ & $15(75.0)$ & $25(125.0)$ & $66(110.0)$ \\
\hline
\end{tabular}

Table 2:-The occurrence of Salmonella species on the vegetables under study.

\begin{tabular}{|l|l|l|l|l|}
\hline Organisms & $\begin{array}{l}\text { Cabbage }(\%) \\
\mathrm{n}=20\end{array}$ & $\begin{array}{l}\text { African spinach }(\%) \\
\mathrm{n}=20\end{array}$ & $\begin{array}{l}\text { Jute-leaf }(\%) \\
\mathrm{n}=20\end{array}$ & $\begin{array}{l}\text { Total } \\
\mathrm{N}=60\end{array}$ \\
\hline Salmonella typhi & $0(0.0)$ & $0(0.0)$ & $1(5.0)$ & $1(1.7)$ \\
\hline Salmonella typhimurium & $9(45.0)$ & $3(15.0)$ & $8(40.0)$ & $20(33.3 \%)$ \\
\hline Salmonella paratyphi A & $0(0.0)$ & $1(5.0)$ & $0(0.0)$ & $1(1.7)$ \\
\hline Other Salmonella & $2(10.0)$ & $1(5.0)$ & $1(5.0)$ & $4(6.7)$ \\
\hline
\end{tabular}

Table 3:-Mean zone of inhibition and sensitivity status of Enterobacter species, Citrobacter species, Providentia species, Klebsiella species, Pseudomonas aeruginosa and Escherichia coli against tested antibiotics.

\begin{tabular}{|c|c|c|c|c|c|c|}
\hline \multirow[b]{3}{*}{ Antibiotics } & \multicolumn{6}{|c|}{ Mean inhibition diameter $( \pm \mathrm{Se})$ of bacteria } \\
\hline & \multicolumn{2}{|c|}{ Enterobacter species } & \multicolumn{2}{|c|}{ Citrobacter species } & \multicolumn{2}{|c|}{ Providentia species } \\
\hline & $\begin{array}{ll}\text { Zone } & \text { of } \\
\text { inhibition } & \\
\end{array}$ & Sensitivity & $\begin{array}{ll}\text { Zone } & \text { of } \\
\text { inhibition } & \\
\end{array}$ & Sensitivity & $\begin{array}{l}\text { Zone of } \\
\text { inhibition }\end{array}$ & Sensitivity \\
\hline $\operatorname{GEN}(5 \mu \mathrm{g})$ & $15.3 \pm 1.04$ & $\mathrm{~S}$ & $7.5 \pm 0.07$ & $\mathrm{R}$ & $6.4 \pm 0.05$ & $\mathrm{R}$ \\
\hline 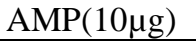 & 0 & $\mathrm{R}$ & 0 & $\mathrm{R}$ & 0 & $\mathrm{R}$ \\
\hline AUG $(30 \mu \mathrm{g})$ & $3.0 \pm 0.02$ & $\mathrm{R}$ & 0 & $\mathrm{R}$ & $4.5 \pm 0.01$ & $\mathrm{R}$ \\
\hline $\mathrm{OFL}(5 \mu \mathrm{g})$ & $23.0 \pm 1.13$ & $\mathrm{~S}$ & $19.1 \pm 1.31$ & $\mathrm{~S}$ & $23.5 \pm 1.07$ & $\mathrm{~S}$ \\
\hline 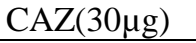 & $14.0 \pm 0.81$ & $\mathrm{R}$ & $16.6 \pm 1.12$ & $\mathrm{~S}$ & $22.5 \pm 1.22$ & $\mathrm{~S}$ \\
\hline CRX $(30 \mu \mathrm{g})$ & $8.9 \pm 0.51$ & $\mathrm{R}$ & $7.5 \pm 0.14$ & $\mathrm{R}$ & $10.0 \pm 0.23$ & $\mathrm{R}$ \\
\hline \multirow[t]{2}{*}{$\mathrm{CPR}(5 \mu \mathrm{g})$} & $21.1 \pm 1.24$ & $\mathrm{~S}$ & $17.3 \pm 1.74$ & $\mathrm{R}$ & $24.0 \pm 1.28$ & $\mathrm{~S}$ \\
\hline & \multicolumn{2}{|c|}{ Klebsiella species } & \multicolumn{2}{|c|}{ Pseudomonas aeruginosa } & \multicolumn{2}{|l|}{ Escherichia coli } \\
\hline GEN $(5 \mu \mathrm{g})$ & $9.7 \pm 0.73$ & $\mathrm{R}$ & $11.5 \pm 1.12$ & $\mathrm{R}$ & $18.5 \pm 0.65$ & $\mathrm{~S}$ \\
\hline $\operatorname{AMP}(10 \mu \mathrm{g})$ & $1.2 \pm 0.01$ & $\mathrm{R}$ & 0 & $\mathrm{R}$ & $5.0 \pm 0.06$ & $\mathrm{R}$ \\
\hline AUG $(30 \mu \mathrm{g})$ & $2.4 \pm 0.03$ & $\mathrm{R}$ & 0 & $\mathrm{R}$ & $6.0 \pm 0.05$ & $\mathrm{R}$ \\
\hline OFL $(5 \mu \mathrm{g})$ & $18.4 \pm 1.06$ & $S$ & $21.5 \pm 1.33$ & $\mathrm{~S}$ & $20.5 \pm 1.24$ & $\mathrm{~S}$ \\
\hline
\end{tabular}




\begin{tabular}{|l|l|l|l|l|l|l|}
\hline CAZ $(30 \mu \mathrm{g})$ & $13.0 \pm 1.13$ & $\mathrm{R}$ & $15.5 \pm 1.04$ & $\mathrm{R}$ & $19.0 \pm 1.17$ & $\mathrm{~S}$ \\
\hline CRX $(30 \mu \mathrm{g})$ & $2.0 \pm 0.01$ & $\mathrm{R}$ & $15.0 \pm 0.68$ & $\mathrm{R}$ & $14.0 \pm 1.12$ & $\mathrm{R}$ \\
\hline CPR $(5 \mu \mathrm{g})$ & $21.6 \pm 1.41$ & $\mathrm{~S}$ & $24.0 \pm 1.31$ & $\mathrm{~S}$ & $17.0 \pm 1.32$ & $\mathrm{~S}$ \\
\hline
\end{tabular}

Key: GEN $=$ gentamicin, $\mathrm{AMP}=$ ampicillin, $\mathrm{AUG}=$ amoxycyllin/clavulanate, $\mathrm{ORL}=$ ofloxacin, $\mathrm{CAZ}=$ ceftazidime, $\mathrm{CRX}=$ cefuroxime, $\mathrm{CPR}=$ ciprofloxacin, $\mathrm{R}=$ resistance, $\mathrm{S}=$ sensitive.

Table 4:-Mean zone of inhibition and sensitivity status of Vibrio species, Proteus species, Alcaligenes species, Salmonella typhimurium, Salmonella paratyphi A and other salmonellae against tested antibiotics.

\begin{tabular}{|c|c|c|c|c|c|c|}
\hline \multirow[b]{3}{*}{ Antibiotics } & \multicolumn{6}{|c|}{ Mean inhibition diameter $( \pm \mathrm{Se})$ of bacteria } \\
\hline & \multicolumn{2}{|l|}{ Vibrio species } & \multicolumn{2}{|l|}{ Proteus species } & \multicolumn{2}{|c|}{ Alkaligenes species } \\
\hline & $\begin{array}{ll}\text { Zone } & \text { of } \\
\text { inhibition }\end{array}$ & Sensitivity & $\begin{array}{ll}\text { Zone } & \text { of } \\
\text { inhibition } & \end{array}$ & Sensitivity & $\begin{array}{l}\text { Zone of } \\
\text { inhibition }\end{array}$ & Sensitivity \\
\hline GEN $(5 \mu \mathrm{g})$ & 15.4 & $\mathrm{~S}$ & $10.0 \pm 0.08$ & $\mathrm{R}$ & 0 & $\mathrm{R}$ \\
\hline 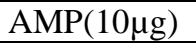 & 0 & $\mathrm{R}$ & 0 & $\mathrm{R}$ & 0 & $\mathrm{R}$ \\
\hline 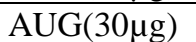 & 0 & $\mathrm{R}$ & $9.5 \pm 0.07$ & $\mathrm{R}$ & 0 & $\mathrm{R}$ \\
\hline OFL $(5 \mu \mathrm{g})$ & 19.6 & $\mathrm{~S}$ & $25.5 \pm 1.53$ & $\mathrm{~S}$ & $21.0 \pm 1.14$ & $\mathrm{~S}$ \\
\hline CAZ $(30 \mu \mathrm{g})$ & 19.7 & $\mathrm{~S}$ & $18.5 \pm 1.24$ & $\mathrm{R}$ & 0 & $\mathrm{R}$ \\
\hline 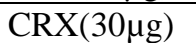 & 9.5 & $\mathrm{R}$ & $9.5 \pm 0.44$ & $\mathrm{R}$ & 0 & $\mathrm{R}$ \\
\hline \multirow[t]{2}{*}{ CPR $(5 \mu \mathrm{g})$} & 22.3 & $\mathrm{~S}$ & $21.5 \pm 1.12$ & $\mathrm{~S}$ & $23.7 \pm 1.21$ & $\mathrm{~S}$ \\
\hline & \multicolumn{2}{|c|}{ Salmonella typhimurium } & \multicolumn{2}{|c|}{ Salmonella typhi/paratyphi $\mathrm{A}$} & \multicolumn{2}{|c|}{ Other Salmonellae } \\
\hline GEN $(5 \mu \mathrm{g})$ & $2.0 \pm 0.02$ & $\mathrm{R}$ & $13.0 \pm 0.16$ & $\mathrm{R}$ & $12.6 \pm 0.84$ & $\mathrm{R}$ \\
\hline 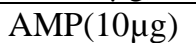 & 0 & $\mathrm{R}$ & 0 & $\mathrm{R}$ & 0 & $\mathrm{R}$ \\
\hline 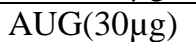 & $3.7 \pm 0.03$ & $\mathrm{R}$ & 0 & $\mathrm{R}$ & $2.0 \pm 0.04$ & $\mathrm{R}$ \\
\hline OFL $(5 \mu \mathrm{g})$ & $11.5 \pm 0.22$ & $\mathrm{R}$ & $25.2 \pm 1.06$ & $\mathrm{~S}$ & $19.0 \pm 1.07$ & $\mathrm{~S}$ \\
\hline 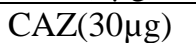 & 0 & $\mathrm{R}$ & $25.2 \pm 1.33$ & $\mathrm{~S}$ & $8.6 \pm 0.09$ & $\mathrm{R}$ \\
\hline 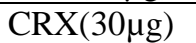 & 0 & $\mathrm{R}$ & $12.2 \pm 0.85$ & $\mathrm{R}$ & 0 & $\mathrm{R}$ \\
\hline CPR $(5 \mu \mathrm{g})$ & $17.3 \pm 1.08$ & $\mathrm{~S}$ & $27.0 \pm 1.36$ & $\mathrm{~S}$ & $19.2 \pm 1.52$ & $\mathrm{~S}$ \\
\hline
\end{tabular}

Key: GEN $=$ gentamicin, $\mathrm{AMP}=$ ampicillin, $\mathrm{AUG}=$ amoxycyllin/clavulanate, $\mathrm{ORL}=$ ofloxacin, $\mathrm{CAZ}=$ ceftazidime, $\mathrm{CRX}=$ cefuroxime, $\mathrm{CPR}=$ ciprofloxacin, $\mathrm{R}=$ resistance, $\mathrm{S}=$ sensitive.

\section{Discussion:-}

Sixty six (66) bacteria isolates belonging to ten bacteria genera were recorded from 60 different collections of vegetables in the present study. Oluyege and Famurewa (2015) isolated some of the organisms isolated in the present study from cooked foods sold in eateries in Ado-Ekiti, Nigeria. The organisms the researchers isolated were: E. coli (31.8\%), Klebsiella spp. (19.4\%), Proteus spp. (17.1\%), Salmonella (14.0\%), Pseudomonas spp. (12.4\%), Shigella spp. (3.8\%) and Enterobacter spp. (1.6\%). These are enteric bacteria. The source of food contamination with the similar bacteria as in the present study might be either from contaminated vegetables or faecal contamination due to food handlers. Moreover, Orunusi (2011) isolated similar organisms such as S. aureus, E. coli, Enterobacter, Salmonella, Klebsiella, Pseudomonas aeruginosa, Proteus, on street vended ready-to-eat fruits (pineapple and water melon).

Bacterial contamination of vegetables in the markets could have been from the farmland, transportation from the farm to the markets or handling by the marketers. Consumption of cabbage, Jute leaves and African spinach sold in the major markets in Ado-Ekiti, Nigeria, may be associated with infections unless the preparation before consumption is done under hygienic conditions. Heat treatment of African spinach is usually minimal because of the need to preserve vitamins which may not withstand too much heat. Such vegetable foods may pose health hazards to the consumers. Of greater concern is cabbage often consumed raw in salad. If cleaning process do not sufficiently decontaminate the vegetable, food poisoning becomes inevitable. It is advocated that vegetables be rinsed in clean water, soaked in a disinfectant solution and afterwards rinsed in clean water before consumption (Rosas et al., 1984). This process will reduce contaminating microorganisms to the barest minimum that may not cause infection. The risk of infection to consumers of vegetables that are irrigated with clean disinfected water may be reduced the minimum. The high technology tertiary treatments and disinfection systems (Hamilton et al., 2006) to achieve such water may not be readily available to farmers; neither the clean water either. This is a challenge in developing countries. Greater effort is therefore needed to prepare vegetables in a most hygienic manner before consumption for food safety purpose. 
The high recorded prevalence of typhoid and bacteria enteritis in Ado-Ekiti (Ajibade, 2012; David et al., 2015) might not be unconnected with presence of Salmonella species on vegetables. The present study appears to support it as the organisms were isolated on all the vegetables investigated.

Organisms isolated in this study were enteric bacteria. This is either a reflection of the sanitary situation in the land or use of contaminated water for irrigation of farmland or vegetable garden (Barber et al., 2007). It is therefore important to control the sources of vegetable contamination.

Decrease in risk for human illness associated with raw vegetables can be further achieved through controlling points of potential contamination such as during harvesting; during processing or distribution; or in retail markets (Beuchat et al., 1997). To reduce the microbiological contamination of vegetables after harvest, proper washing of vegetables with clean water is essential (Eni et al., 2010). Water supplemented with varying concentrations of organic acids, such as citric and, acetic acids (vinegar), has been shown to reduce microbial populations on fruits and vegetables (Eni et al., 2010). After harvest, vegetables should be transported to the market in proper containers (Rosas et al., 1984) in sanitized vehicles allowing adequate air circulation (Brackett et al., 1999).

Most of the isolates recorded gross resistance against the tested antibiotics. Infections caused by the isolates may proof difficult to manage if antibiotic sensitivity testing is ignored. Virtually all the isolates were inhibited by ofloxacin and ciprofloxacin and 100\% resistant to ampicillin, augmentin/clavulanate and cefuroxime is recorded. This agreed with the findings of Oluyege and Famurewa (2015) on enteric pathogens isolated from cooked foods sold in eateries in Ado-Ekiti. Salmonella typhi in the present study was resistant to ceftaxidine and cefuroxime. This result is in agreement with the findings of David et al (2015) who recorded resistance of Salmonella typhi isolated from the oropharynx of some students of Ekiti State University against the antibiotics.

Sufficient heat treatment of vegetables may be needed in preparation of vegetables for consumption to prevent enteric bacterial infection. Vegetables eaten raw such as Cabbage may pose threats to the consumers because of contamination with bacteria.

In conclusion, the general populace may need to be informed of the health risks associated with the consumption of contaminated vegetables. The consumers should always observe the basic principle of food and personal hygiene in handling of vegetables. As vegetables are not usually exposed to sufficient heat to avoid loss of contain nutrients, the nutritional benefits may need to be balanced with the risk of enteric bacterial infection especially in vegetables consumed raw and in places where control of contamination of vegetables is a challenge.

\section{Conflict of interest:}

Not declared.

\section{Funding:}

This study received no form of funding from any organization. It was funded by the authors.

\section{References:-}

1. Adabara, N.U., Ezugwu, B.U., Momojimoh, A., Madzu, A., Hashimu, Z., Damisa, D. (2012): The prevalence and antibiotic susceptibility pattern of Salmonella Typhi patients attending a military hospital in Minna Nigeria. Adv. Preventive Med. 2012: 1-4.

2. CLSI document M100-S23 (M02-A11) (2003): Disc diffusion supplemental tables, Performance standards for antimicrobial susceptibility testing. The complete standard may be obtained from the Clinical and Laboratory Standards Institute, 940 West Valley Road, Suite 1400, Wayne, PA 19807

3. Ajibade, V.A. (2012): Incidence of multidrug resistant; Salmonella sp in some food and meatproducts sold in Ado Ekiti, South Western Nigeria. Int J Sci Innos, 4 (1): 2276 -6154.

4. Avery, L.M., Killham, K. and Jones, D.L. (2005): Survival of E. coli O157: H7 in organic wastes destined for land application. J Appl Microbiol., 98:814-822.

5. Barber, L.B., Lee K.E., Swackhamer, D.L., Schoenfuss, H.L. (2007): Reproductive responses of male fathead minnows exposed to wastewater treatment plant effluent, effluent treated with XAD8 resin, and an environmentally relevant mixture of alkylphenol compounds. Aquat Toxicol., 82 (1):36-46.

6. Barrow, G.I. and Feltam, R.k. (2004): Motility test: Cowan and Steels manual for the identification of medical Bacteria. $3^{\mathrm{r}} \mathrm{d}$ Edition. Cambridge University Press: UK. 
7. Beuchat, L., and Ryu, J. (1997): Produce Handling and Processing Practices. Emerg Infect Dis,3(4): 459-465.

8. Brackett, R.E. (1999): Incidence, Contributing Factors, and Control of Bacterial Pathogens in Produce. Postharvest Biology and Technology, 15(3): 305-311.

9. Brandl, M.T. (2006): Fitness of enteropathogens on plants and implications for food safety. Ann Rev Phytopath., 44:367-392.

10. Chessbrough, M. (2006): District laboratory practice in Tropical countries 2. London: Cambridge University Press.

11. Darwin, K., and Miller, V. (1999): Molecular Basis of the Interaction of with Salmonella the Intestinal Mucosa. Clin Microbiol Rev., 12 (3): 405-428

12. David, O.M., Adedapo D.A., Moro, D.D., Esan C.O., Oje, O.J., Famurewa, O. (2015): Prevalence and carriage status of Salmonella typhi among students of Ekiti State University, Ado-Ekiti, Nigeria. Int J Biosci.,6 (10): 1-8.

13. Eni, A., Oluwawemitan, I., and Solomon, O. (2010): Microbial Quality of Fruitsand Vegetables Sold in Sango Ota, Nigeria. Afr J FoodSci., 4(5):291-296

14. Erkan, E.M. and Vural, A. (2008): Investigation of microbial quality of some leafy green vegetables. J. Food. Tech.,6: 285-288.

15. Farooq, M., Anwar, F. and Rashid, U. (2008): Appraisal of heavy metal contents in different vegetables grown in the vicinity of an industrial area. Pak. J. Bot., 40:2099-2106.

16. Gharavi, M.J, Jahani, M.R. and Rakni, M.B. (2002): Parasitic contamination of vegetables from farms and markets in Tehran. Iranian J. Publ. Health, 31: 83-86.

17. Garrity, G.M., Brenner, D.I, Krieg, E. R., Stanley, J. T. (2005): Bergey’s Manual of Systemic Bacteriology, 2nd edition, volume 2. Springer-Verlag: New York.

18. Hamilton, A., Stagnitti, F., Premier, R., Boland, A., and Hale, G. (2006): Quantitative Microbial Risk Assessment Models for Consumption of RawVegetables Irrigated with Reclaimed Water. Appl Environ Microbiol., 72(5): 3284-3290

19. Heaton, J., Jones, K. (2008): Microbial Contamination of Fruit and Vegetables and the Behaviour of Enteropathogens in the Phyllosphere: A Review. J Appl Microbiol., 104 (3): 613-626

20. Hung H. C., Joshipura K. J., Jiang R. H., Hunter D, Smith S. A. (2004): Fruits and Vegetable intake and the risk of major chronic disease. J Natl Cancer Inst., 95: 157- 164.

21. Ibekwe, A. C., Okonko, I. O., Onunkwo, A. U., Donbraye, E., Babalola,E. T and Onoja, B.A (2008): Baseline Salmonella agglutinin titres in apparently healthy freshmen in Awka, South Eastern, Nigeria. Sci. Res. Essays, 3(9): 225-230.

22. Itanna, F. (2002): Metals in leafy vegetables grown in Addis Ababa and toxicological implication. Ethiop. J. Health Dev., 16: 295-302.

23. Machado, D., Maia, C., Carvalho, I., da Silva, N., Andre, M., and Serafini, A. (2006). Microbiological Quality of Organic Vegetables Produced in Soil Treated with Different Types of Manure and Mineral Fertilizer. Braz. J. Microbiol., 37(4): 538-544

24. Natvig, E.E., Ingham, S.C., Ingham, B.H., Cooperband, L.R., and Roper, T.R. (2002): Salmonella enterica serovar Typhimurium and Escherichia coli contamination of root and leaf vegetables grown in soils with incorporated bovine manure. Appl Environ Microbiol., 68:2737-2744.

25. Nguyen-the, C., and Carlin, F. (1994): The Microbiology of Minimally Processed Fresh Fruits and Vegetables. Crit Rev Food Sci Nutr., 34 (4): 371-401

26. Olusegun, O. (2013). Urban expansion and urban land use in Ado Ekiti, Nigeria. American Journal of Research communication, 1 (2): 128-139.

27. Oluyege, A. O., Babalola, J. A., Igbalajobi, A. O. and Oloruntuyi, A. B. (2015): Isolation and characterization of Salmonella typhi from Widal positive patients attending Ekiti State University Teaching Hospital. Int J. Curr. Microbol. App. Sci., 4 (10): 774-784.

28. Oluyege, O. A. and Famurewa, O. (2015): Microbial Contamination and Antibiotic Resistance in Enteric Pathogens Isolated from Cooked Foods Sold in Eateries in Ado-Ekiti, Nigeria. British Microbiology Research Journal, 6(4): 236-246.

29. Oranusi, S., Olorunfemi, O. J. (2011): Microbiological safety evaluation of street vended ready-to-eat fruits sold in Ota, Ogun state, Nigeria. Int J biol Sci., 1 (3): 22-26.

30. Rosas, I., Baez, A., and Coutino, M. (1984): Bacteriological Quality of Crops Irrigated with Wastewater in the Xochimilco Plots, Mexico City, Mexico. Appl Envern Microbiol., 47 (5): 1074-1079.

31. WPR [World Population Review] (2018). Population of cities in Nigeria. Accessed online at http://worldpopulationreview.com/countries/nigeria-population/cities/ 18/06/2019 5:22PM. 
32. Yusuf, I. Z., Oyaweye, O. M., Yongabi, K. A., Pemu A. T. (2004). Bacteriological Quality Assessment of Salad Vegetables sold in Bauchi Metropolis. Nigeria Journal of Microbiology. 18: 316-320. 